\title{
Legal Status of Village-level Head River Administrator
}

\author{
Feiming Li \\ Law School \\ Sichuan Agricultural University \\ Ya'an, China \\ Email: 847796447@qq.com
}

\begin{abstract}
-the system of village-level river is a system innovation based on the implementation of the National "head river administrator system". At present, all parts of the country have encountered a series of legal problems in the reform of village-level head river administrator system. Its root cause lies in the lack of legal basis for the legal status of village-level river leaders. Based on the practice of reform, this paper puts forward that the village-level river head is a new legal subject which is different from the provincial, municipal, county and township river heads, and its essence is the combination of villagers 'autonomy and administrative authorization.
\end{abstract}

Keywords: village-level head river administrator; environmental protection; villagers autonomy

\section{INTRODUCTION}

The nineteenth Congress of the Communist Party of China once again focused on ecological and environmental protection. "Accelerating the reform of the ecological and cultural system and building a beautiful China" means that China's environmental governance system will continue to undergo in-depth reform. The head river administrator system is one of the important systems for water environmental protection. In 2016, the Central Committee of the Communist Party of China and the State Council issued the "Opinions on the Comprehensive Implementation of the Head river administrator System" and implemented the "Head river administrator System" throughout the country. The Law of the People's Republic of China on the Prevention and Control of Water Pollution clarifies the legal status of the provincial, municipal, county, and township rivers. On this basis, all parts of the country have carried out the exploration of the village-level head river administrator system. The Sichuan Provincial Environmental Protection Administration Regulations clearly stipulates: "Encourage the establishment of village-level head river administrator system." The upper law provides the legal basis for the establishment of the village-level head river administrator system. The village-level head river administrator and above and the village-level head river administrator are all part of the "head river administrator system" in China. The management responsibilities are also roughly the same, but from the legal point of view, However, there are obvious differences in the legal nature of the two, which leads to unclear legal status. This paper will discuss this issue in order to solve the difficulties in this reform.

\section{ANALYSIS OF THE LEGAL PARTICULARITY OF VILLAGE RIVER LEADERS}

\section{A. The Legal Basis for Establishment is Different}

The establishment of river heads above the township level is mainly based on Article 5 of the "Water Pollution Prevention and Control Law": "The establishment of river heads in provinces, cities, counties, and townships", while the establishment of village-level river heads is mainly based on local regulations or rules. Specifically to Sichuan Province, Its legal basis is Article 26 of the "Sichuan Provincial Environmental Protection Regulations": "Encourage the establishment of village-level head river administrator systems or river patrol systems." According to Article 72 of the "Legislative Law," "The people's Congresses of provinces, autonomous regions, and municipalities directly under the Central Government and their standing committees may formulate local regulations based on the specific conditions and actual needs of their respective administrative regions and on the premise that different constitutions, laws, and administrative regulations contravene each other. The "Sichuan Provincial Environmental Protection Regulations" is a further provision of the local law based on specific circumstances and actual needs. Local regulations and central legislation are the relationship between "sub-law" and "mother law". Local regulations themselves have the characteristics of dependence because of the main purpose of implementing central legislation, and have the characteristics of autonomy because of the inherent local legislative authority. The legislative basis of the river heads at the township level and above and the legislative basis of the village-level river heads system belong to the upper law and the lower law[1]. The former is the National People's Congress and its Standing Committee, and the latter is the local people's Congress and its Standing Committee; In terms of the level of effectiveness of the two, the legal effect of the former is higher than that of the latter.

\section{B. The Identity of the Subject is Different}

According to the "Opinions on the Comprehensive Implementation of the River System," "The provinces, autonomous regions, and municipalities directly under the Central Government set up the head of the river, and the party committee or the government is mainly responsible for the comrades; In the administrative areas of provinces(autonomous regions and municipalities directly 
under the Central Government), the heads of rivers and lakes are set up and the responsible comrades at the provincial level serve as the heads of rivers and lakes; Each city, county, and township where the river and lake are located are set up in stages and are headed by responsible comrades at the same level. "It can be seen that the heads of rivers at and above the township level are party and government officials and are civil servants; The village-level river heads, whether they are cadres of village (residential) committees or other ordinary personnel, do not have the status of civil servants, which is significantly different from the former. Because civil servants "perform their public duties in accordance with the law, are included in the state administration, and the state finances pay wages and benefits", they have special professional attributes and have their own job requirements of "safeguarding the public interest". The head river administrator system is an institutional innovation in our country to improve the water governance system and ensure the country's water safety. Therefore, the head river administrator function also has the attribute of "maintaining public interests", although in this respect, the head river administrator and the civil servants 'work attributes coincide. However, the village-level river chief did not obtain civil service status because of his work as a river director. Therefore, in essence, the nature of the two identities is still completely different. Because there is a clear difference between the identity of the heads of rivers at the township level and above and that of village-level rivers, when considering the establishment of village-level head river administrator systems, its production methods and management and supervision models can not be completely equivalent to the heads of rivers at the township level and above. Different institutional design.

\section{Different Focus of Village-level Head River Administrator Legislation}

According to the "Opinions on the Comprehensive Implementation of the River System," "We insist on party and government leadership and departmental linkage. We will establish and improve a system of responsibilities with the Party and government leadership as the core, clarify the responsibilities of river leaders at all levels, strengthen work measures, coordinate the efforts of all parties, and form a work pattern that will be implemented at the first level and at the next level. "The focus of the work of river heads at the township level and above is on coordinating leadership and implementing responsibilities; The village-level river chief lacks administrative authority and does not mobilize various kinds of resources. $\mathrm{He}$ is at the executive level in the river system. His positioning should be "inspector", "information officer", "persuasion officer" or "supervisor". In local legislation, the village-level river chief system legislation is generally consistent with the upper law in terms of legislative purposes, legislative purposes, and legislative principles, and has logical consistency, but because of the differences in power between the township and above river heads and the village-level river heads. Further lead to its scope of responsibility, work content, etc. will be significantly different, village-level river long system of legislative focus is bound to have a big difference with the former.

\section{The Legal Relationship between the Village River Chief and the Village Committee is not Clear}

The establishment of the village-level head river administrator system is an extension of the system made by the local government on the basis of the four-level head river administrator system at the provincial, municipal, county and township levels in order to implement the spirit of the CPC Central Committee and the State Council's "Opinions" and solve the "last kilometer" problem of river and lake management and protection. Theoretically, it belongs to the "head river administrator system" as a large institutional system. Although the work of the village-level river leaders is temporarily sent to village cadres or ordinary villagers in practice, in practice, village-level river leaders are not necessarily The village committee has a subordinate relationship; Although the second paragraph of Article 8 of the Organic Law of the Village People's Committee stipulates: "The Village People's Committee manages the land and other property owned by the village farmers collectively in accordance with the law, guides the villagers in the rational use of natural resources, and protects and improves the ecological environment. However, this provision is intended to give responsibility to the village committee based on the villagers 'autonomy. The personnel of the village-level river system may overlap with the cadres of the village committee, and the work responsibilities may also overlap. However, it is obvious that the village committee can not naturally form a legal affiliation with the village river leader. The legal relationship between the two should be based on the way the village river leader is produced.

\section{E. The Generation of Village-level Head River Administrator is Unreasonable}

In the local legislation, it is an important problem that the generation of village-level river heads is unknown. As mentioned earlier, village-level river leaders are independent of the working status of village cadres, and their establishment does not have to be equivalent to that of village cadres. In terms of personnel arrangements, we need to design rivers at the grassroots level according to their working characteristics and combined with the methods of grass-roots governance. We need to consider their rationality at the institutional level, and we need to refer to the basic concept of the duties of river heads at the village level and the basic content of democratic governance at the grassroots level. Considering the way of its production in many aspects and formulating a reasonable way for the generation and appointment and removal of river heads at the village level, we can further clarify the scope of responsibilities, divide rights and obligations, and establish a system of river heads at the village level with high feasibility and strong working results.

Due to the aforementioned problems in the establishment of the village-level head river administrator system, the source of responsibility is not yet clear. On the one hand, the village-level river chief is not under the 
management of the village committee. On the other hand, if the rights and obligations of the village-level river chief are clarified by signing an agreement, the agreement itself will also be controversial in terms of its nature. And if only one administrative commission or civil agreement is used to create a source for the functions of the village river chief, its work functions may not be clear, the work effect is not ideal, the supervision method is not perfect, and the accountability method is not specific.

\section{CONSIDERATION OF THE LEGAL STATUS OF VILLAGE RIVER LEADERS}

The river head administrator system is a characteristic measure of river governance in China. To clarify the legal status of head river administrator, it is possible to clarify the duties and rights of each main body in river governance [2]. As an extension of the system of provincial, municipal, county, and township river heads, the village-level river chief system legislation must also clarify its legal positioning and solve the practical dilemma of village-level river heads who are "non-statutory". Although the Opinions on the Comprehensive Implementation of the River System promulgated at the end of 2016 are documents at the national level, from the point of view of legal sources, they are normative in nature and do not belong to legal norms. The establishment of the village-level river system based solely on the "Opinions on the Comprehensive Implementation of the River System" is obviously insufficient at the legal level [3]. From the perspective of reform practices across the country, most regions have promoted this reform mainly through administrative orders, making this work considered by many scholars to be a sports work with temporary, assault characteristics and lack of internal lasting motivation.

Firstly, in order to solve the problem that the legal position of the village river chief is unclear, the author believes that it should be clearly stipulated through local legislation. The specific idea is that, since the heads of rivers at the village level do not have the status of civil servants, it should be made clear in the local law that the heads of rivers at the village level take the villagers 'autonomy as their main function and do not belong to the new legal subjects of the administrative organs. In the absence of conflict with the superior law, it can carry out corresponding administrative authorization.

Secondly, the legal relationship between the village-level river chief and the village committee should be clarified. This is the necessary premise and legal basis for solving the responsibility source of village-level river chief, and it is also a necessary consideration before constructing the village-level river chief supervision model. As autonomous organizations of the local masses, the duties of the village committees are based on the autonomy of the villagers, and the duties of the village river heads are based on local legislative authorization or entrusted methods. Although the duties of the village river heads and village committees overlap, However, it belongs to two different legal systems. In the management relationship, there is no possibility of "block" combined with leadership. It is obviously more appropriate that the management or supervision of the village-level river chief be directly borne by the superior river chief. Therefore, village river chiefs and village committees can be identified as parallel "support" relationships through local regulations.

Thirdly, the source of responsibility of the village river leaders should be clearly defined. This relates to the effective performance of the village river leaders 'duties and the completion of their work goals. The village-level head river administrator system forms a long-term operation mechanism. In view of the fact that the village river chief does not have the status of a civil servant, it is not appropriate to adopt an administrative order. When local legislation assigns functions to village river chiefs, because of their natural person status, they exclude the possibility of obtaining administrative functions due to the authorization of laws, regulations, regulations, etc., but village river chiefs may have the possibility of exercising administrative functions because of administrative entrustment. Local legislation may, within the limits of its powers, specify the matters that may be entrusted to it, and allow the relevant administrative organs to entrust specific administrative matters to the heads of rivers at the village level so that they may have certain administrative functions and exercise their functions in the name of the entrusted organs. So that it can use administrative resources to perform its functions, it also helps to give full play to the basic social governance function of village river leaders. On this basis, it is possible to consider the signing of an agreement between the local administrative organ and the village river chief to clarify the scope of responsibility of the village river chief. The specific work items, financial support, and the responsibilities of the village river chief should be included in the agreement. The agreement is administrative in nature. First, one party is a citizen and the other is a local administrative organ. Second, the ultimate purpose of the agreement signed by the two parties is to meet the needs of comprehensive water management and environmental protection and to safeguard public interests. Finally, the content of the agreement involves a large number of administrative law rights and obligations. The agreement signed by the two parties completely has several elements of the administrative agreement. Its nature is an administrative agreement, and it is neither a civil entrustment contract nor a labor contract.

The legal position of the village-level river chief system in the entire river chief system is determined by the signing of administrative agreements. The rights and obligations of village-level river heads are therefore clear, and legal accountability methods can be found in terms of responsibility, and based on the advantages of administrative contracts. Where necessary in the public interest, the administrative authority may change or terminate the contract with an individual.

Specifically to the method of selecting the personnel of the village-level river head, the author believes that it can be decided by the village committee recommendation, the villagers themselves, the township and township people's governments, and the sub-district offices. The township people's government has the final decision power. In terms of efficiency, the method is reasonable. 
In summary, only by clarifying the legal nature and legal status of the village river leaders can we build a scientific and reasonable system.

\section{REFERENCES}

[1] $\mathrm{Hu}$ yuhong. Try to talk about the legal status of the standard--Combined with status problem between the administrative regulations and local regulations, Chinese Legal Science.2004,no,3.

[2] Chen Meixuan. From River Governor System to River Governor Management: On the Theoretical Basis and Practical Innovation of the River Governor Management, journal of central south university of forestry \& technology,2018,(12)02,6-11.

[3] Zhu Mei. On the Development and Promotion of River Governor System, Environmental Protection,2017,Z1. 